\section{Gas Exchange and Growth of Transplanted and Nontransplanted Field-grown Shumard Red Oak Trees Grown with and without Organic Mulch}

\author{
Thayne Montague ${ }^{1,3}$ and Lindsey Fox ${ }^{2}$ \\ Department of Plant and Soil Science, Texas Tech University, Lubbock, \\ $T X 79409-2122$
}

Additional index words. Quercus shumardii, establishment, water deficit stress

\begin{abstract}
Gas exchange and growth of transplanted and nontransplanted, mulched and nonmulched field-grown Shumard red oak trees (Quercus shumardii Buckli.) were investigated in a semiarid climate. In Spring 2003, 12 field-grown trees were selected for uniformity. Six trees were moved with a tree spade and six trees were undisturbed. In addition, pine bark mulch was applied around three randomly selected transplant and nontransplant trees. Soil volumetric water content, predawn leaf water potential, midday stomatal conductance $\left(g_{S}\right)$ and leaf temperature, and growth data were collected over three consecutive growing seasons. Throughout the experiment, weekly predawn leaf water potential and $g_{S}$ data indicate transplanted trees with and without mulch were under greater water stress when compared with nontransplanted trees. In addition, nontransplanted trees with mulch were under greater stress when compared with nontransplanted trees without mulch. Each year, transplanted trees and nontransplanted trees with mulch had less apical growth when compared with nontransplanted trees without mulch. Although gas exchange and apical growth of transplanted trees and nontransplanted mulched trees tended to increase each growing season, by experiment termination, gas exchange and apical growth for transplanted trees and nontransplanted trees with mulch did not recover to nontransplanted, nonmulch tree levels.
\end{abstract}

Field-grown (FG) trees lose a significant portion of their root system (Gilman and Beeson, 1996) and when transplanted are subjected to great stress. Water deficits often develop (Montague et al., 2000a) because the natural balance between root absorptive area and transpiring leaf area is disrupted (Kramer and Kozlowski, 1979). In addition, roots often do not grow rapidly enough to

Received for publication 26 Nov. 2007. Accepted for publication 6 Jan. 2008.

This research was supported in part by a grant from the State of Texas Higher Education Coordinating Board and the J. A. Love Endowment fund. This work represents a portion of a thesis submitted by L. Fox for the Masters in Horticulture degree at Texas Tech University.

We thank Tom Scarborough of Tom's Tree Place for support of this project.

Mention of a trademark, proprietary product, or vendor does not constitute a guarantee or warranty of the product by Texas Tech University and does not imply its approval to the exclusion of other products or vendors that also may be suitable.

Manuscript No. T-4-585 of the College of Agricultural Sciences and Natural Resources.

${ }^{1}$ Associate Professor.

${ }^{2}$ Former graduate student. Current address: U.S. Department of Agriculture, Agriculture Research Service, Cropping Systems Research Laboratory, Lubbock, TX 79415.

${ }^{3}$ To whom reprint requests should be addressed; e-mail thayne.montague@ttu.edu exchange and growth of transplanted FG trees in arid and semiarid climates has been minimal and establishment rates for transplanted FG trees in such regions need to be determined.

Reduced soil moisture evaporation is one of the benefits organic mulch (pine bark, pruning chips, pine needles, and so on) provides in landscapes (Kraus, 1998; Montague et al., 2000b). Several researchers indicate transplanted trees surrounded by organic mulch have enhanced apical (shoot elongation, leaf area increase, and so on) (Green and Watson, 1989; Hensley et al., 1988) and root growth (Green and Watson, 1989; Watson and Kupkowski, 1991) when compared with trees grown without mulch. However, many authors report transplanted woody plant growth is not influenced or is reduced by organic mulch (Arnold et al., 2005; Gilman and Grabosky, 2004; Hild and Morgan, 1993; Montague et al., 2000b). Despite lack of evidence from replicated research and potential long-term adverse consequences, organic mulch continues to be recommended as a cultural method to assist establishment of transplanted trees (Herms et al., 2001).

An additional concern is placement of organic mulch around established landscape trees. Little research has been published that documents if gas exchange and growth are altered when organic mulch is placed on soil surrounding established trees. Watson (1988) reports root growth of several established tree species that had been surrounded by organic mulch (wood chips placed on soil 20 years after trees were planted). When compared with trees not surrounded by mulch, root density of mulched trees was greater for some species but less for others. In a similar study, Fraedrich and Ham (1982) placed organic mulch (wood chips) around established maple species (planted 4 years before initiation of mulch study). They report growth was affected by mulch treatments, but once again, response varied with species.

Early and successful growth of a transplanted FG tree's root system after transplanting would greatly increase survivability and establishment. However, environmental factors found in arid climates can increase plant stress and delay establishment (Montague et al., 2000a, 2000b). Although mulch is reported to affect gas exchange and growth of bare root and containerized tree species, little research is available on whether organic mulch influences establishment of newly transplanted, large-caliper FG trees in arid regions. In addition, research documenting if gas exchange and growth are altered when organic mulch is placed on the soil surface surrounding existing trees has been conducted on a limited number of species in mesic climates. If organic mulch reduces physiological processes and growth on transplanted tree species, it is logical to conclude organic mulch may also inhibit these processes on established trees. Therefore, objectives of this experiment were to compare the influence of organic mulch on gas exchange and growth of transplanted and 
nontransplanted, large-caliper FG Shumard red oak trees grown in a semiarid climate.

\section{Materials and Methods}

Research was conducted at a commercial field nursery located in Lubbock, TX (U.S. Dept. of Agriculture hardiness zone 7a). In 1994, seedling Shumard red oak trees were planted in an Amarillo fine sandy loam soil (fine-loamy, mixed, superactive thermic Aridic Paleustalfs). Trees were planted $4.5 \mathrm{~m}$ apart in a north-south row. Until initiation of the experiment, irrigation and fertilization practices were consistent with commercial field nurseries in this area. In Mar. 2003, 12 trees were selected for uniformity (based on height and trunk caliper $15 \mathrm{~cm}$ above soil level). At transplanting, mean tree height was $5.1 \mathrm{~m}$ and mean tree caliper was $10.2 \mathrm{~cm}$. On 21 Mar. 2003, six planting holes were dug at original tree spacing with a $2.3-\mathrm{m}$ hydraulic tree spade (Burkeen Manufacturing Co., Olive Branch, MS) and each hole was enlarged slightly. After holes were dug, six uniform trees were randomly selected and moved with the tree spade to a previously dug planting hole. All trees conformed to specifications of the American Association of Nurserymen Standards (American Standard for Nursery Stock, 1996). After transplanted trees were placed into planting holes, twothirds of native soil was backfilled and trees were irrigated with $75 \mathrm{~L}$ of water. Native soil was then placed around each root ball until soil level reached existing grade. To decrease irrigation runoff, a low berm (2.3-m diameter circle) was formed around the base of each tree. At this time, all trees were irrigated (transplanted and nontransplanted) with a total of $189 \mathrm{~L}$ of water. Each week throughout the growing season (mid-April through October), each tree received $95 \mathrm{~L}$ of water applied directly to the area within the berm of each tree. Three transplanted and three nontransplanted trees were randomly selected and steel landscape edging (10.2-cm wide, 14-gauge steel landscape edging; Collier Metal Specialties, Garland, TX) was placed around the base of selected trees to form a 2.3-m diameter circle. On 29 Mar., composted pine bark mulch (screened to $\approx 5.0$ $\mathrm{cm})$ was placed around trees with steel edging to a depth of $10.2 \mathrm{~cm}$. Pine bark mulch was maintained at this depth throughout the experiment. Four treatment combinations existed: mulch, nontransplanted; mulch, transplanted; nonmulch, nontransplanted; and nonmulch, transplanted. Throughout the study, trees were not pruned, weeds were removed by hand, and fertilizer was not applied.

Throughout each growing season, predawn $\psi_{\mathrm{L}}$ was measured $6 \mathrm{~d}$ after irrigation. Leaf water potential was measured at $0600 \mathrm{HR}$ (Central Daylight Time) on two randomly selected, mature leaves from each tree. Leaves were excised before dawn, immediately sealed in a plastic bag, and placed in a portable cooler (Karlic and Richter, 1979). Water potential was measured within $30 \mathrm{~min}$ of excision with a pressure chamber (model 3005; Soilmoisture Corp., Santa Barbara, CA). Weekly predawn $\psi_{\mathrm{L}}$ was taken as the mean of six measurements for each treatment combination. On the same day, weekly predawn $\psi_{\mathrm{L}}$ was measured, midday (1200 to $1400 \mathrm{HR}) g_{\mathrm{S}}$ was measured. Conductance was measured with a steady-state porometer (model LI-1600; LI-COR, Lincoln, NE). For data collection purposes, single trees of each treatment combination were paired and one measurement cycle included a tree from each treatment combination. Cycles were repeated until all trees were measured. Stomatal conductance data were recorded on four fully expanded sun leaves and two fully expanded shade leaves from each tree. On the same day predawn $\psi_{\mathrm{L}}$ and $g_{\mathrm{S}}$ were measured, soil volumetric water content (WV) was estimated by inserting a soil moisture sensor (model CS 620; Campbell Scientific, Logan, UT) to a 12-cm depth in the soil. Four separate measurements (one in each cardinal direction) were taken $\approx 30 \mathrm{~cm}$ inside the berm or metal edging surrounding each tree. Mulch was moved aside when necessary. Mean $g_{\mathrm{S}}$ and WV for each treatment combination were taken as the mean of 18 or 12 measurements, respectively.

Each year before budbreak (and again in October), trunk diameter $15 \mathrm{~cm}$ above soil level was measured on each tree using a digital caliper (model 500-196; Mitutoyo Corp., Kanagawa, Japan). For each tree, stem cross-sectional area increase was determined as the difference between spring and fall measurements. In the spring of each year, 10 randomly selected shoots on each tree were selected and shoot elongation (based on growth from bud scales to the terminal bud) was measured in late fall. Yearly shoot elongation for each treatment combination was taken as the mean of 30 shoots. Each year, subsample leaf area was also measured on each tree. To obtain subsample leaf area, 100 randomly selected leaves from each tree were removed in the fall and measured with a portable leaf area meter (model LI-3000 with LI-3050A conveyor attachment; LI-COR). Subsample leaf area for each treatment combination was taken as the mean of 300 leaves. An automated weather station (Model Medtata1; Campbell Scientific, Inc.) was used to monitor and collect local weather data. Sensors were scanned every $10 \mathrm{~s}$ and hourly means recorded. Grass reference evapotranspiration (ETo) was calculated using ETo calculation software (Allen, 2000).

The experimental design was a twoby-two factorial arranged in a completely randomized design with two transplant treatments and two mulch treatments. Within each treatment, trees were replicated three times. Mean predawn $\psi_{\mathrm{L}}$ and midday $g_{\mathrm{S}}$ for each treatment were plotted against weeks after transplanting (WAT) for 2003, 2004, and 2005 (data were collected on five occasions during the 2005 growing season). Mean weekly and mean growing season predawn $\psi_{\mathrm{L}}$, midday $g_{\mathrm{S}}$ and WV data, and all growth data were analyzed in SAS (version 9.1 for
Windows; SAS Institute, Inc., 2001) based on a completely randomized design. If significant differences were found, means were separated by Fisher's LSD procedure $(P \leq 0.05)$.

\section{Results and Discussion}

All trees survived transplanting and appeared healthy throughout the experiment. During each growing season, total ETo was at least two times greater than total precipitation. Greatest total ETo occurred during the 2005 growing season $(140.5 \mathrm{~cm})$, whereas the lowest total ETo occurred during the 2004 growing season $(118.8 \mathrm{~cm})$. Greatest total precipitation occurred during the 2004 growing season $(43.5 \mathrm{~cm})$ and the least total precipitation was during the 2003 growing season $(20.2 \mathrm{~cm})$. Measurements of soil volumetric water content indicate mulched trees had greater soil moisture when compared with nonmulched trees (data not presented). In addition, the first 13 weeks after transplanting, soil volumetric water content for nontransplanted trees was less when compared with soil volumetric water content for transplanted trees. However, for the remainder of the experiment, differences in soil moisture between transplanted and nontransplanted trees were not found. Our results verify those that have compared soil moisture for soils covered with organic mulch with nonmulched soils (Kraus, 1998; Montague et al., 2000b).

Weekly (Fig. 1) and overall predawn $\psi_{\mathrm{L}}$ means (Table 1) for each growing season also reveal treatment differences. Predawn $\psi_{\mathrm{L}}$ data from 2003 indicate transplanted trees without mulch were under greater water deficit stress (more negative $\psi_{\mathrm{L}}$ ) when compared with trees from other treatments. Results from 2004 again indicate transplanted trees without mulch were under greater water deficit stress when compared with trees from other treatments. However, 2004 data indicate nontransplanted trees with mulch were under greater water deficit stress when compared with nontransplanted trees without mulch. Data from the final growing season reveal nontransplanted trees without mulch under the least amount of water deficit stress and transplanted trees without mulch under the greatest amount of water deficit stress.

Our results are similar to those that have compared $\psi \mathrm{L}$ and shoot water potential $\left(\psi_{\mathrm{S}}\right)$ of transplanted and nontransplanted FG trees. In Florida, Gilman and Beeson (1996) observed $\psi_{\mathrm{S}}$ for transplanted FG laurel oak (Quercus laurifolia Michx.) and 'East Palatka' holly (Ilex $\times$ attenuata Ashe) irrigated with $40 \mathrm{~L}$ everyday the first 14 WAT and $60 \mathrm{~L}$ every other day thereafter. They report transplanted trees needed 15 to 40 WAT to recover to nontransplant $\psi_{\mathrm{S}}$ levels. In an arid climate, Montague et al. (2000a) found predawn $\psi_{\mathrm{L}}$ of transplanted Norway maple (A. platanoides L. 'Schwedleri') and littleleaf linden (Tilia cordata Mill. 'Greenspire') trees (irrigated with $38 \mathrm{~L}$ each week) needed 18 WAT and 


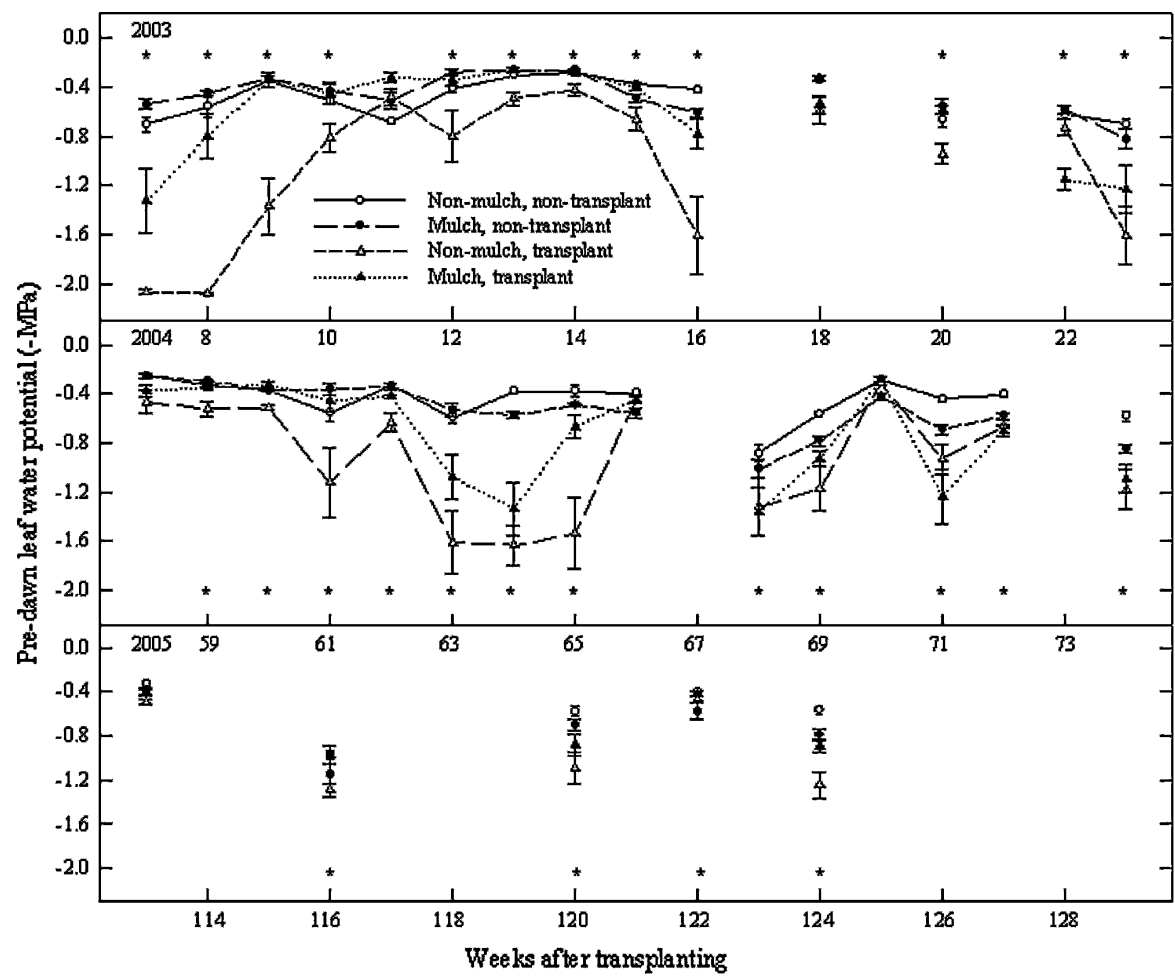

Fig. 1. Effects of transplanting and organic mulch on predawn leaf water potential of Shumard red oak (Quercus shumardii) trees during the 2003, 2004, and 2005 growing seasons. Each point is the mean of six measurements. Asterisks indicate significant effects of transplanting or mulch at the $5 \%$ level by $\mathrm{F}$ test. Vertical bars represent sEs of the mean.

Table 1. Effects of pine bark mulch and transplanting on predawn leaf water potential and midday $g_{\mathrm{S}}$ for field-grown Shumard red oak (Quercus shumardii) trees during the 2003, 2004, and 2005 growing seasons. ${ }^{\mathrm{z}}$

\begin{tabular}{|c|c|c|c|c|c|c|}
\hline & \multicolumn{3}{|c|}{$\begin{array}{c}\text { Predawn leaf } \\
\text { water potential (MPa) }\end{array}$} & \multicolumn{3}{|c|}{ Midday $g_{\mathrm{S}}\left(\mathrm{mmol} \cdot \mathrm{m}^{-2} \cdot \mathrm{s}^{-1}\right)$} \\
\hline & 2003 & 2004 & 2005 & 2003 & 2004 & 2005 \\
\hline \multicolumn{7}{|l|}{ Treatment } \\
\hline Transplant & - & - & - & - & - & $88.1 \mathrm{~b}^{\mathrm{y}}$ \\
\hline Nontransplant & - & - & - & - & - & $107.4 \mathrm{a}$ \\
\hline Mulch & - & - & - & - & - & 93.4 \\
\hline Nonmulch & - & - & - & - & - & 101.6 \\
\hline Nonmulch, nontransplant & $-0.49 \mathrm{a}^{\mathrm{x}}$ & $-0.45 \mathrm{a}$ & $-0.61 \mathrm{a}$ & $89.5 \mathrm{a}$ & $163.9 \mathrm{a}$ & - \\
\hline Mulch, nontransplant & $-0.46 \mathrm{a}$ & $-0.54 \mathrm{~b}$ & $-0.72 \mathrm{~b}$ & $76.8 \mathrm{~b}$ & $117.9 \mathrm{~b}$ & - \\
\hline Nonmulch, transplant & $-1.05 \mathrm{c}$ & $-0.94 \mathrm{~d}$ & $-0.89 \mathrm{c}$ & $32.3 \mathrm{c}$ & $96.1 \mathrm{c}$ & - \\
\hline Mulch, transplant & $-0.63 \mathrm{~b}$ & $-0.74 \mathrm{c}$ & $-0.71 \mathrm{~b}$ & $35.8 \mathrm{c}$ & $95.6 \mathrm{c}$ & - \\
\hline Significance & & & & & & \\
\hline Transplant & 0.001 & 0.001 & 0.023 & 0.001 & 0.001 & 0.008 \\
\hline Mulch & 0.001 & 0.208 & 0.535 & 0.017 & 0.001 & 0.295 \\
\hline Mulch $\times$ transplant & 0.001 & 0.006 & 0.016 & 0.001 & 0.001 & 0.911 \\
\hline
\end{tabular}

${ }^{2}$ Each estimate is the mean of all measurements taken each growing season.

${ }^{y}$ Mean separation between surface and transplant treatments by LSD $(P \leq 0.05)$.

${ }^{x}$ Mean separation between surface $\times$ transplant treatment interaction by LSD $(P \leq 0.05)$

LSD $=$ least significant difference.

over two growing seasons, respectively, to recover to nontransplant predawn $\psi_{\mathrm{L}}$ levels.

As was the case in our study, water deficit stress often develops when FG trees are transplanted (Montague et al., 2000a). Without mulch and with limited irrigation, E and evaporation can accelerate drying of the root ball (Watson and Kupkowski, 1991) and lead to deficit moisture stress. For large nontransplanted trees, fibrous root density is greatest near the soil surface and at or past the tree's drip line (Watson, 2005). Because FG trees lose a significant portion of their root system, after transplanting, water outside the root ball is largely unavailable to a newly transplanted tree (Watson and Kupkowski, 1991) and water uptake within the root ball occurs more slowly through older, suberized roots (Kramer and Kozlowski, 1979). For transplanted FG trees, new root growth originates primarily from the ends of severed roots (Watson and Himelick, 1982) and, depending on species, can take many weeks to initiate (Arnold and Struve, 1989). For transplanted trees in this study, it appears minimal root growth (and therefore water uptake) occurred within the root ball. However, we found predawn $\psi_{\mathrm{L}}$ of transplanted trees to be less negative when the root ball of a transplanted tree was covered with mulch. Because restoration of a transplanted tree's water balance is associated with root regeneration (Kramer, 1987), the more rapid recovery of predawn $\psi_{\mathrm{L}}$ for mulched, transplanted trees compared with nonmulched transplanted trees was likely the result of increased soil moisture within the root ball, which allowed transplanted trees with mulch to have more rapid root growth and water uptake.

Each season, weekly and overall $g_{\mathrm{S}}$ means indicate differences between nontransplanted mulch and nontransplanted nonmulch trees, but no differences between transplanted nonmulch trees and transplanted mulch trees. For the 2003 and 2004 growing seasons, nonmulch, nontransplanted trees generally had greater midday $g_{\mathrm{S}}$ when compared with trees of remaining treatments (Fig. 2; Table 1). Also, transplanted trees regardless of mulch treatment tended to have lower midday $g_{S}$ when compared with trees from remaining treatments. For the 2005 growing season, there were no treatment interactions for $g_{\mathrm{S}}$ data (Table 1); therefore, only main treatment effects were analyzed. However, $g_{S}$ data from 2005 followed similar trends as earlier data.

Results are similar to previous work conducted on gas exchange of transplanted and nontransplanted trees. Kjelgren and Cleveland (1994) report reduced $g_{\mathrm{S}}$ the first two growing seasons after transplanting FG Kentucky coffee tree (Gymnocladus dioicus L.) but not in transplanted FG silver maple (Acer saccharinum L.). They attribute $g_{\mathrm{S}}$ differences between species to the fibrous root system of silver maple being able to extract more soil water when compared with the coarse root system of Kentucky coffee tree. In addition, Montague et al. (2000a) compared gas exchange ( $g_{\mathrm{S}}$ and $\left.\mathrm{PN}\right)$ of transplanted and nontransplanted Norway maple and littleleaf linden trees. They report gas exchange of transplanted Norway maple was reduced for a single growing season, whereas gas exchange of transplanted littleleaf linden did not return to nontransplanted rates after two growing seasons.

Data from each growing season indicate apical growth was reduced for trees that received mulch or were transplanted. Shoot elongation was greatest for nonmulched, nontransplanted trees and similar (except for the 2005 growing season) for trees that received mulch or were transplanted (Table 2 ). There was not a treatment interaction for stem cross-sectional area increase; therefore, each year, main effects were analyzed. Stem cross-sectional area of nontransplanted trees was $49 \%$ to $87 \%$ greater when compared with transplanted trees and $40 \%$ to $76 \%$ greater for trees that were not mulched (Table 2). Leaf 


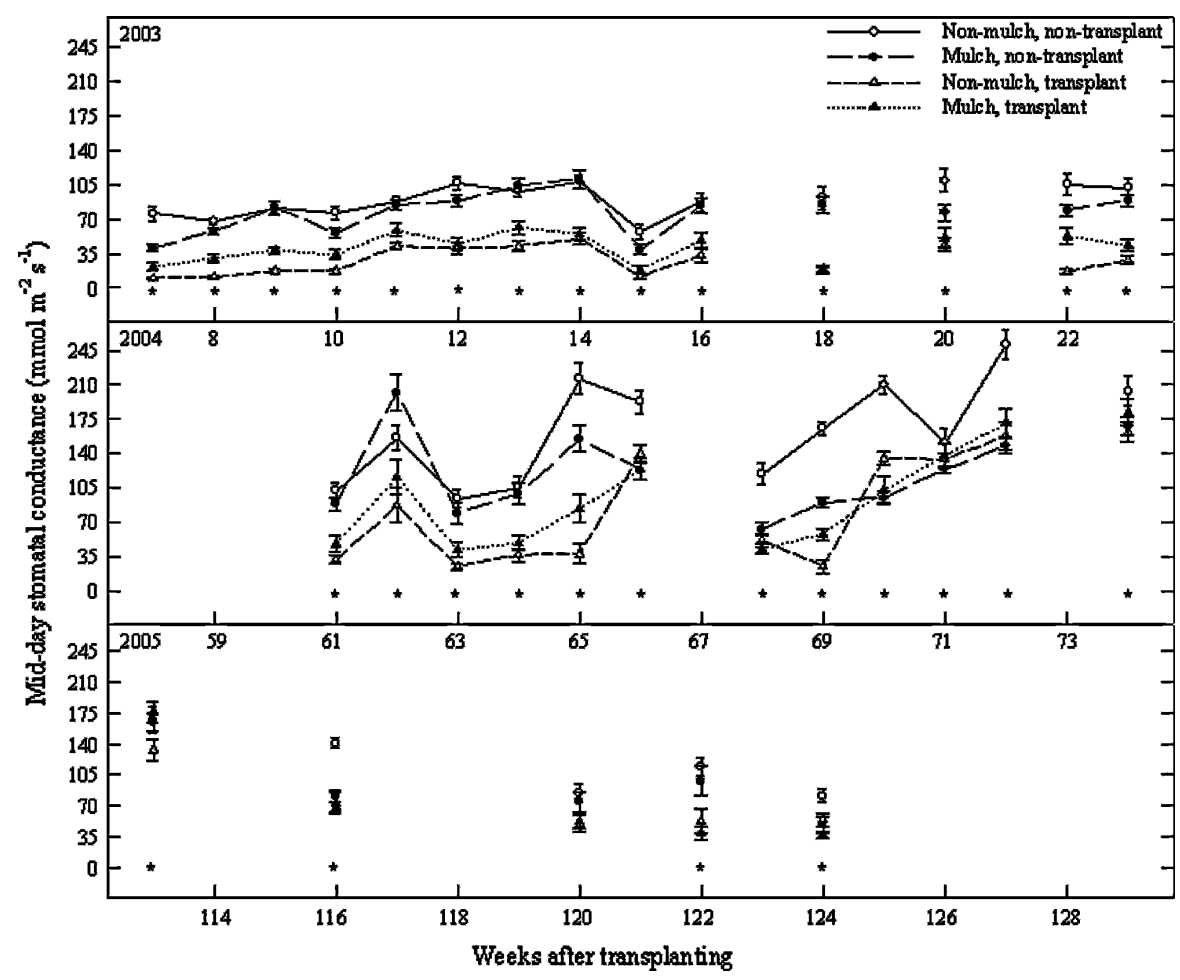

Fig. 2. Effects of transplanting and organic mulch on midday $g_{\mathrm{S}}$ of Shumard red oak (Quercus shumardii) trees during the 2003, 2004, and 2005 growing seasons. Each point is the mean of 18 measurements. Asterisks indicate significant effects of transplanting or mulch at the $5 \%$ level by $\mathrm{F}$ test. Vertical bars represent SEs of the mean.

area data followed a similar trend as shoot elongation data. Each growing season, leaves of nonmulched, nontransplanted trees had the greatest leaf area, and leaves of nonmulched, transplanted trees had the least leaf area (Table 2).

Montague et al. (2000a) reports similar reductions in stem cross-sectional area, shoot elongation, and leaf size for transplanted Norway maple and littleleaf linden trees after two growing seasons. Similarly, Kjelgren and Cleveland (1994) found reduced growth for transplanted Kentucky coffee tree and silver maple trees when compared with nontransplanted trees. Apical growth of transplanted trees was likely reduced by several factors. To avoid desiccation and conserve water, many plants close stomata in response to increasing E (Monteith, 1995; Mott and Parkhurst, 1991). However, when stomata close, growth may be sacrificed because PN is reduced (Kozlowski, 1982; Kramer, 1987) and respiration may increase as a result of greater leaf temperature (Kramer and Kozlowski, 1979). In addition, for optimum growth, each tree species has a specific root:shoot ratio (Kramer and Kozlowski, 1979). If this ratio is altered (by pruning roots or shoots), assimilates are directed to replace removed tissue (Gilman, 1992). Because transplanted trees in our study lost a significant portion of their root system, vigorous top growth would likely not occur until the species-specific root:shoot ratio is restored (Gilman, 1992). Reduced leaf area also limited carbon assimilation by reducing PN capability (Montague et al., 2000a). Water deficit stress can also limit apical growth of trees by reducing mineral uptake and assimilation, hormone synthesis, $g_{\mathrm{S}}$, and $\mathrm{PN}$ (Kuhns and Gjerstad, 1988).

Research has been limited investigating the influence organic mulch may have on establishment of transplanted FG trees. However, Montague et al. (2007) investigated the influence of organic mulch on establishment of several newly transplanted containerized shrub species. They report containerized crape myrtle (Lagerstoremia indica L. 'Victor'), forsythia (Forsythia $\times$ intermedia Zab. 'Lynwood'), and spiraea (Spiraea $\times$ vanhouttei Zab.) transplants had greater gas exchange and growth when grown with organic mulch when compared with transplants grown without organic mulch (bare soil). However, they report no difference for gas exchange or growth between photinia (Photinia $\times$ fraseri Dress.) transplants grown with and without organic mulch. In a semiarid climate, Kraus (1998) found organic mulch assisted establishment of containerized desert willow (Chilopsis linearis Cav. 'Burgundy') transplants. Increased root and shoot growth of desert willow transplants with mulch was attributed to greater soil moisture in mulched soils when compared with nonmulched soils. Our data indicate for transplanted FG Shumard red oak, the addition of organic mulch to the soil surface may hasten tree establishment. We found transplanted trees grown with organic mulch tended to have less negative predawn $\psi_{\mathrm{L}}$ and similar or greater growth when compared with transplanted trees grown without mulch (Tables 1 and 2; Figs. 1 and 2). Because restoration of a transplanted tree's water balance is associated with root regeneration (Kramer, 1987), increased gas exchange and growth of mulched, transplanted Shumard red oak trees when compared with nonmulched,

Table 2. Effects of pine bark mulch and transplanting on shoot elongation, stem cross-sectional area, and individual leaf area for field-grown Shumard red oak (Quercus shumardii) trees during the 2003, 2004, and 2005 growing seasons.

\begin{tabular}{|c|c|c|c|c|c|c|c|c|c|}
\hline & \multicolumn{3}{|c|}{$\begin{array}{l}\text { Shoot elongation } \\
(\mathrm{cm})\end{array}$} & \multicolumn{3}{|c|}{$\begin{array}{l}\text { Stem area increase } \\
\left(\mathrm{cm}^{2}\right)\end{array}$} & \multicolumn{3}{|c|}{$\begin{array}{l}\text { Leaf area } \\
\left(\mathrm{cm}^{2}\right)\end{array}$} \\
\hline \multicolumn{10}{|l|}{ Treatment } \\
\hline Mulch & - & - & - & $5.1 \mathrm{~b}$ & $4.4 \mathrm{~b}$ & $10.4 \mathrm{~b}$ & - & - & - \\
\hline Nonmulch & - & - & - & $8.5 \mathrm{a}$ & $18.3 \mathrm{a}$ & $21.5 \mathrm{a}$ & - & - & - \\
\hline Nonmulch, nontransplant & $17.9 \mathrm{a}^{\mathrm{y}}$ & $26.5 \mathrm{a}$ & $25.5 \mathrm{a}$ & - & - & - & $24.9 \mathrm{a}$ & $30.8 \mathrm{a}$ & $34.1 \mathrm{a}$ \\
\hline Mulch, transplant & $4.5 \mathrm{~b}$ & $6.2 \mathrm{~b}$ & $8.3 \mathrm{c}$ & - & - & - & $19.2 \mathrm{~b}$ & $22.9 \mathrm{~b}$ & $32.4 \mathrm{~b}$ \\
\hline Significance & & & & & $P>\mathrm{F}$ & & & & \\
\hline Transplant & 0.003 & 0.001 & 0.001 & 0.024 & 0.013 & 0.0322 & 0.901 & 0.001 & 0.196 \\
\hline Mulch & 0.018 & 0.001 & 0.001 & 0.008 & 0.007 & 0.041 & 0.001 & 0.001 & 0.004 \\
\hline Transplant $\times$ mulch & 0.011 & 0.001 & 0.001 & 0.829 & 0.885 & 0.129 & 0.001 & 0.001 & 0.001 \\
\hline
\end{tabular}

${ }^{2}$ Mean separation between surface and transplant treatments by LSD $(P \leq 0.05)$.

${ }^{\mathrm{y}}$ Mean separation between surface $\times$ transplant treatment interaction by LSD $(P \leq 0.05)$. 
transplanted trees were likely the result of increased soil moisture within the root ball (Kraus, 1998). For transplanted FG Shumard red oak trees, organic mulch appears to moderate the soil environment such that root growth is greater when compared with nonmulched, transplanted trees. Because of water deficit stress associated with root loss, gas exchange and growth were reduced during each growing season for all transplanted trees. Criteria used to determine when transplanted trees become established are recovery of $\psi_{\mathrm{L}}$, gas exchange, and growth rates when compared with nontransplanted tree levels (Beeson and Gilman, 1992; Watson, 1985). Using these parameters, transplanted FG Shumard red oak trees (grown with or without mulch) were not established after three growing seasons.

Although organic mulch increased gas exchange and growth of transplanted FG Shumard red oak trees, the addition of organic mulch to the soil surface surrounding nontransplanted FG Shumard red oak trees reduced tree gas exchange and growth (Tables 1 and 2; Figs. 1 and 2). Nontransplanted FG Shumard red oak trees surrounded with just a $2.3-\mathrm{m}$ diameter circle of organic mulch had more negative predawn $\psi_{\mathrm{L}}$, reduced $g_{\mathrm{S}}$, and reduced apical growth when compared with nontransplanted FG Shumard red oak trees that did not receive an organic mulch treatment. Fraedrich and Ham (1982) indicate growth response of established maple species (Acer rubrum L., A. saccharum Marsh., and A. saccharinum L.) to wood chip mulch varied with growth parameter (stem diameter, shoot growth, or height) and species. Watson (1988) reports established red maple (A. rubrum $\mathrm{L}$. 'Bowhall'), 'Emerald Queen' Norway maple, sugar maple (A. saccharum Marsh.'Green Mountain'), green ash (Fraxinus pennsylvanica Marsh.), and littleleaf linden trees were grown 20 years in a field nursery setting without organic mulch. Six years after organic mulch was added to the soil surface (10 to $12 \mathrm{~cm}$ mulch depth), mulched trees had increased root density and fine root growth when compared with trees grown with a bare soil surface. However, red oak (Q. rubra L.) and pin oak ( $Q$. palustris Muenchh.) trees grown under identical circumstances had similar or lower root density and little fine root growth when compared with trees grown with bare a bare soil surface. Watson (1988) reports greater soil moisture content within and below mulch may be a factor that inhibits root growth of some oak species. As a result of greater soil moisture content, Hild and Morgan (1993) suggest shrub species native to semiarid regions placed in irrigated landscapes may not benefit from organic mulch. This response may also be true for tree species. In native regions, Shumard red oak prefers a well-drained soil (Arnold, 2002; Dirr, 1998) but may be found along streams and in low-lying areas (Dirr, 1998). Therefore, greater soil moisture content brought about when placing organic mulch in landscapes may be a factor that could reduce gas exchange and restrict root and shoot growth of established Shumard red oak trees.

In addition to increased soil moisture, organic mulch influences soil temperature (Montague et al., 2000b) and soil aeration (Watson, 1988). Gas exchange and growth of oak species appear to be sensitive to reduced soil temperatures (Cochard et al., 2000; Lyr and Garbe, 1995; Teskey and Hinckley, 1981) and reduced soil aeration (Costello et al., 1991). Although root zone temperature was not measured in the current study, it is likely reduced root zone temperature (which can influence plant hormone levels and plant water relations) (Cochard et al., 2000; Lyr and Garbe, 1995) brought on by organic mulch influenced gas exchange and growth of nontransplanted trees. To confirm this hypothesis, investigating long-term response of established oak species to organic mulch should be a concern for horticulture scientists.

Because tree species differ in sensitivity to transplanting stress, arborists, landscape contractors, and horticulturists working with transplanted FG trees in landscapes should be aware of the time required for transplanted trees to become established in arid climates. When transplanting FG trees, precautions need to be taken that ensure tree survival. In addition, our research confirms tolerance to organic mulch should be considered before recommending organic mulch when landscaping below established trees. Cultural practices such as the use of organic mulch and planting species that establish rapidly in semiarid conditions may increase survival of transplanted FG trees and therefore reduce future maintenance and replacement costs.

\section{Literature Cited}

Allen, R.G. 2000. REF-ET. Reference evapotranspiration software. Windows version 2.01.17. Dept. Biol. and Agr. Eng., Univ. ID., Moscow.

American Standard for Nursery Stock. 1996. Z60.1-1996. Amer. Assn. Nurserymen, Washington, DC.

Arnold, M.A. 2002. Landscape plants for Texas and environs. 2nd ed. Stipes Publishing, Champaign, IL.

Arnold, M.A., G.V. McDonald, and D.L. Bryan. 2005. Planting depth and mulch thickness affect establishment of green ash (Fraxinus pennsylvanica) and bougainvillea goldenraintree (Koelreuteria bipinnata). J. Arboricult. 31:163-170.

Arnold, M.A. and D.K. Struve. 1989. Green ash establishment following transplant. J. Amer. Soc. Hort. Sci. 114:591-595.

Beeson, R.C. and E.F. Gilman. 1992. Diurnal water stress during landscape establishment of slash pine differs among three production methods. J. Arboricult. 18:281-287.

Cochard, H., R. Martin, P. Gross, and M.B. BogeatTriboulot. 2000. Temperature effects on hydraulic conductance and water relations of Quercus robur L. J. Expt. Bot. 51:12551259.

Costello, L.R., J.D. MacDonald, and K.A. Jacobs. 1991. Soil aeration and tree health: Correlating oxygen measurements with the decline of established oaks. USDA Forest Service Gen. Tech. Rep. PSW-126:295-299.

Dirr, M.A. 1998. Manual of woody landscape plants: Their identification, ornamental characteristics, culture, propagations and uses. 5th ed. Stipes Publishing, Champaign, IL.

Farquhar, G.D. 1978. Feedforward responses of stomata to humidity. Aust. J. Plant Physiol. 5:787-800.

Fraedrich, S.W. and D.L. Ham. 1982. Wood chip mulching around maples: Effect on tree growth and soil characteristics. J. Arboricult. $8: 85-89$.

Gilman, E.F. 1992. Effect of root pruning prior to transplanting on establishment of southern magnolia in the landscape. J. Arboricult. 18:197-200.

Gilman, E.F. and R.C. Beeson. 1996. Production method affects tree establishment in the landscape. J. Environ. Hort. 14:81-87.

Gilman, E.F. and J. Grabosky. 2004. Mulch and planting depth affect live oak (Quercus virginiana Mill.) establishment. J. Arboricult. 30: 311-316.

Green, T.L. and G.W. Watson. 1989. Effects of turfgrass and mulch on the establishment and growth of bare-root sugar maples. J. Arboricult. 15:268-272.

Hensley, D.L., R.E. McNiel, and R. Sundheim. 1988. Management influences on growth of transplanted Magnolia grandiflora. J. Arboricult. 14:204-207.

Herms, D., M. Gleason, J. Iles, D. Lewis, H. Hoitink, and J. Hartman. 2001. Using mulches in managed landscapes. Iowa Agr. Expt. Sta. Bul. 894.

Hild, A.L. and D.L. Morgan. 1993. Mulch effects on crown growth of five Southwestern shrub species. J. Environ. Hort. 11:41-43.

Hinckley, T.M., R.G. Aslin, R.R. Aubuchon, C.L. Metcalf, and J.E. Roberts. 1978. Leaf conductance and photosynthesis in four species of the oak-hickory forest type. For. Sci. 24:7384.

Karlic, H. and H. Richter. 1979. Storage of detached leaves and twigs without changes in water potential. New Phytol. 83:379-384.

Kjelgren, R. and B. Cleveland. 1994. Growth and water relations of Kentucky coffee tree and silver maple following transplanting. J. Environ. Hort. 12:96-99.

Kozlowski, T.T. 1982. Water supply and tree growth. I. Water deficits. For. Abst. 43:57-95.

Kramer, P.J. 1987. The role of water stress in tree growth. J. Arboricult. 13:33-38.

Kramer, P.J. and T.T. Kozlowski. 1979. Physiology of woody plants. Academic Press, New York, NY.

Kraus, H.T. 1998. Effects of mulch on soil moisture and growth of desert willow. HortTechnology 8:588-590.

Kuhns, M.R. and D.J. Gjerstad. 1988. Photosynthate allocation in loblolly pine (Pinus taeda) seedlings as affected by moisture stress. Can. J. For. Res. 18:285-291.

Lyr, H. and V. Garbe. 1995. Influence of root temperature on growth of Pinus sylvestris, Fagus sylvatica, Tilia cordata and Quercus robur. Trees (Berl.) 9:220-223.

Montague, T., R. Kjelgren, and L. Rupp. 2000a. Gas exchange and growth of two transplanted, field-grown tree species in an arid climate. HortScience 35:763-768.

Montague, T., R. Kjelgren, and L. Rupp. 2000b. Surface energy balance affects gas exchange and growth of two irrigated landscape tree species in an arid climate. J. Amer. Soc. Hort. Sci. 125:299-309. 
Montague, T., C. McKenney, M. Maurer, and B. Winn. 2007. Influence of irrigation volume and mulch on establishment of select shrub species. Arboricult. Urban For. 33:202-209.

Monteith, J.L. 1995. A reinterpretation of stomatal responses to humidity. Plant Cell Environ. 18:357-364.

Mott, K.A. and D.F. Parkhurst. 1991. Stomatal responses to humidity in air and helox. Plant Cell Environ. 14:509-515.

SAS Institute, Inc. 2001. The SAS system for windows. Release 9.1. SAS Inst., Cary, NC.
Teskey, R.O. and T.M. Hinckley. 1981. Influence of temperature and water potential on root growth of white oak. Physiol. Plant. 52:363-369.

Turner, N.C., E.D. Schulze, and T. Gollan. 1984 The responses of stomata and leaf gas exchange to vapour pressure deficits and soil water content. I. Species comparisons at high soil water contents. Oecologia 63:338342.

Watson, G.W. 1985. Tree size affects root regeneration and top growth after transplanting. J. Arboricult. 11:37-40.
Watson, G.W. 1988. Organic mulch and grass competition influence tree root development. J. Arboricult. 14:200-203.

Watson, G.W. and E.B. Himelick. 1982. Root distribution of nursery trees and its relationship to transplanting success. J. Arboricult. 8:225-229.

Watson, G.W. and G. Kupkowski. 1991. Soil moisture uptake by green ash trees after transplanting. J. Environ. Hort. 9:227-230.

Watson, W.T. 2005. Influence of tree size on transplant establishment and growth. HortTechnology 15:118-122. 